\title{
Folate Antagonist
}

National Cancer Institute

\section{Source}

National Cancer Institute. Folate Antagonist. NCI Thesaurus. Code C511.

A compound with a chemical structure similar to folic acid. Folate antagonists inhibit one or more folate-dependent enzymes, resulting in decreased DNA, RNA and protein synthesis. 